\title{
The prevalence and impact of eating disorder behaviours in Australian men
}

\author{
Deborah Mitchison ${ }^{1 *}$, Jonathan Mond ${ }^{2}$, Shameran Slewa-Younan ${ }^{3}$, Phillipa Hay ${ }^{4}$ \\ From 2013 ANZAED Conference: Inspiring Change: Person and Context \\ Melbourne, Australia. 23-24 August 2013
}

\section{Objective}

To determine sex differences in the prevalence and associated impairment of eating disorder (ED) features over time.

\section{Method}

Cross-sectional surveys of randomly selected adults were carried out in $1998(\mathrm{n}=3010)$ and $2008(\mathrm{n}=3034)$. Outcomes included self-reported health-related quality of life (HRQoL), objective and subjective binge eating, extreme dieting, purging, and overevaluation of weight or shape.

\section{Results}

Men represented 23 - 41\% of participants who reported ED features. Objective binge eating was associated with greater reductions in mental HRQoL in men compared to women $(\mathrm{p}<0.05)$, whereas overevaluation of weight or shape was associated with greater reductions in HRQoL in women compared to men $(\mathrm{p}<0.05)$. The prevalence of extreme dieting and purging increased at a faster rate in men compared to women ( $\mathrm{p}=0.03)$, whereas the rate of increase in objective binge eating was similar between the sexes ( $p>0.05)$. Mental HRQoL impairment associated with binge eating had increased over time for men but not for women $(\mathrm{p}<0.05)$.

\section{Conclusions}

The gender gap in the prevalence and impact of ED behaviours may be closing. Implications include the need for more gender-neutral public health campaigns and interventions, and the active inclusion of male participants in ED research.

* Correspondence: debbie.mitchison@gmail.com

${ }^{1}$ School of Medicine, University of Western Sydney, Australia

Full list of author information is available at the end of the article
This abstract was presented in the Disordered Eating Characteristics \& Treatment stream of the 2013 ANZAED Conference.

\begin{abstract}
Authors' details
${ }^{1}$ School of Medicine, University of Western Sydney, Australia. ${ }^{2}$ Centre for Applied Psychology, University of Canberra, Australia. ${ }^{3}$ School of Medicine, University of Western Sydney, Australia. ${ }^{4}$ Centre for Health Research, School of Medicine, University of Western Sydney, Australia.
\end{abstract}

Published: 14 November 2013

doi:10.1186/2050-2974-1-S1-023

Cite this article as: Mitchison et al:: The prevalence and impact of eating disorder behaviours in Australian men. Journal of Eating Disorders 2013 1(Suppl 1):O23.

Submit your next manuscript to BioMed Central and take full advantage of:

- Convenient online submission

- Thorough peer review

- No space constraints or color figure charges

- Immediate publication on acceptance

- Inclusion in PubMed, CAS, Scopus and Google Scholar

- Research which is freely available for redistribution
(0) 2013 Mitchison et al; licensee BioMed Central Ltd. This is an Open Access article distributed under the terms of the Creative Commons Attribution License (http://creativecommons.org/licenses/by/2.0), which permits unrestricted use, distribution, and reproduction in any medium, provided the original work is properly cited. 